\title{
Carboxypeptidase Q
}

National Cancer Institute

\section{Source}

National Cancer Institute. Carboxypeptidase Q. NCI Thesaurus. Code C92657.

Carboxypeptidase Q $(472 \mathrm{aa}, \sim 52 \mathrm{kDa}$ ) is encoded by the human CPQ gene. This protein plays a role in the hydrolysis of proteins and circulating peptides. 